\title{
PROSES PEMAKAIAN KATA SERAPAN DAN ISTILAH ASING DALAM OPINI PADA HARIAN SERAMBI INDONESIA
}

\author{
Nuraiza $^{(1)}$, Vera Wardani ${ }^{(2)}$ \\ ${ }^{1,2}$ Program Studi Bahasa Indonesia FKIP Universitas Jabal Ghafur Sigli \\ Email: ${ }^{1}$ nuraiza59@gmail.com, ${ }^{2}$ verawardani5@ gmail.com
}

\begin{abstract}
ABSTRAK
Tujuan penelitian ini adalah mendeskripsikan proses pemakaian kata serapan dan istilah asing dalam opini pada surat kabar harian Serambi Indonesia. Penelitian ini menggunakan metode deskriptif kualitatif. Sumber data penelitian ini adalah opini-opini pada Harian Serambi Indonesia yang dimuat pada edisi Februari 2019. Data penelitian ini adalah kata serapan dan istilah asing yang terdapat pada kalimat dalam opini pada Harian Serambi Indonesia edisi Februari 2019. Teknik pengumpulan data menggunakan teknik dokumentasi melalui tahapantahapan; membaca, mengidentifikasi, dan mengumpulkan kalimat yang menggunakan kata serapan dan istilah asing. Adapun teknik pengolahan data meliputi tahapan-tahapan; mendeskripsikan data, mengelompokkan data, menganalisis data, dan menarik simpulan. Hasil analisis data ditemukan bahwa proses pemakaian kata serapan dan istilah asing dalam opini pada Harian Serambi Indonesia edisi Februari 2019 terdapat tiga bentuk proses, yaitu (1) proses adopsi, (2) proses adaptasi, dan (3) proses morfologis afiksasi. Proses adopsi ditemukan pada istilah asing dari bahasa Inggris, bahasa Arab, dan bahasa daerah Aceh. Proses adaptasi ditemukan pada kata serapan dari bahasa Inggris dan bahasa Arab. Adapun proses morfologis afiksasi hanya ditemukan pada kata serapan dari bahasa Inggris. Dalam penelitian ini ditemukan adanya proses adopsi istilah dari bahasa Aceh karena rata-rata opini dalam Serambi Indonesia hampir semua penulis berasal dari Aceh.
\end{abstract}

Kata kunci: kata serapan, istilah asing, opini.

\section{Latar Belakang}

Bahasa merupakan salah satu bagian terpenting dalam kehidupan manusia karena setiap manusia dalam berbagai aktivitas dan kehidupannya selalu berhubungan erat dengan bahasa. Dalam perkembangannya bahasa berkembang maju perlahan-lahan sebagaimana manusia berkembang. Hal tersebut ternyata juga menimpa bahasa Indonesia. Akibat dari perkembangan zaman, perkembangan dalam bahasa Indonesia pun juga terjadi karena menuruti tuntutan globalisasi. Tuntutan globalisasi ini bisa dilihat dari semakin banyaknya gejala bahasa Indonesia yang mulai dimasuki oleh bahasa asing, semisal bahasa daerah, Arab, Inggris, dan lain-lain (Ohoiwutun, 2007:16).

Penggunaan berbagai bahasa asing seperti penggunaan kata serapan dan istilah asing dalam masyarakat dengan berbagai tujuan secara tidak langsung disebabkan oleh tidak adanya padanan kata yang tepat dan sesuai untuk menggantikan suatu kata tertentu, baik secara arti maupun konsep dari kata yang dimaksud. Hal tersebut dikarenakan adanya dampak dari kontak budaya dengan kontak kebahasaan. Misalnya, objek penggunaan kata serapan dan istilah asing sering kita jumpai dalam media massa, seperti surat kabar. Salah satu surat kabar yang dimaksud adalah surat kabar harian Serambi Indonesia. Harian Serambi Indonesia merupakan sebuah surat kabarharian yang terbit di Banda Aceh, Aceh sejak 9 Februari 1989.

Dalam surat kabar pemakaian kata serapan dan istilah asing sering digunakan tanpa adanya penyesuaian dengan padanan kata bahasa Indonesia yang sesuai. Misalnya, pada kolom rubrik Opini. Opini-opini tersebut tentunya ditulis oleh berbagai kalangan. Karena ditulis oleh berbagai kalangan dan beragam masalah, seringkali dalam tulisan rubrik Opini 
ditemukan bermacam penggunaan bahasa serapan dan istilah asing. Alasan penulis menggunakan kata serapan dan istilah asing dalam tulisan opininya tentu berbagai alasan.

Namun, di balik pemakaian kata serapan dan istilah asing dalam tulisan opini-opini tersebut patut dikaji proses pemakaiannya. Oleh sebab itu, perlu sebuah kajian ilmiah untuk menjawab sebuah tujuan, yaitu mengetahui proses pemakaian kata serapan dan istilah asing. Berpijak dari uraian di atas, peneliti akan menganalisis proses pemakaian kata serapan dan istilah asing yang terdapat dalam opini pada Harian Serambi Indonesia.

\section{Kajian Teori \\ Pengertian Bahasa}

Menurut Wibowo (2001:55), bahasa adalah sistem simbol bunyi yang bermakna dan beratikulasi (dihasilkan oleh alat ucap) yang bersifat arbriter dan konvensional, yang dipakai sebagai alat berkomunikasi oleh sekelompok manusia untuk melahirkan perasaan dan pikiran. Adapun Tarigan (1994:16) memberikan dua definisi bahasa. Pertama, bahasa adalah suatu sistem yang sistematik, barang kali juga untuk sistem generatif. Kedua, bahasa adalah seperangkat lambang-lambang makna suka atau simbolsimbol arbriter.

Bahasa adalah sebuah sistem, artinya, bahasa dibentuk oleh sejumlah komponen yang berpola secara tetap dan dapat dikaidahkan. Sistem bahasa berupa lambanglambang bunyi, setiap lambang bahasa melambangkan sesuatu yang disebut makna atau konsep. Karena setiap lambang bunyi itu memiliki atau menyatakan suatu konsep atau makna, maka dapat disimpulkan bahwa setiap suatu ujaran bahasa memiliki makna, Chaer dan Leonie Agustina (2004:32).

Dengan demikian, bahasa dapat diartikan sebagai alat untuk menyampaikan sesuatu yang terlintas di dalam hati. Namun, lebih jauh bahasa adalah alat untuk beriteraksi atau alat untuk berkomunikasi, dalam arti alat untuk menyampaikan pikiran, gagasan, konsep atau perasaan.

\section{Kata Serapan dan Istilah Asing}

Dalam Kamus Umum Bahasa Indonesia, unsur serapan didefenisikan sebagai berikut: unsur adalah bahan asal, zat asal, bagian yang terpenting dalarn suatu hal, sedangkan serapan adalah pemasukan ke dalam, penyerapan masuk ke dalam lubang-lubang kecil (Poerwadarminta, 1985:130).

Menurut Samsuri (1994:50) serapan adalah "pungutan". Adapun Kridalaksana (2011:8) memahami kata serapan adalah "pinjaman" yaitu bunyi, fonem, unsur gramatikal atau unsur leksikal yang diambil dari bahasa lain. Kata serapan adalah kata yang diserap dari berbagai bahasa lain, baik dari bahasa daerah maupun dari bahasa asing, yang digunakan dalam bahasa Indonesia yang cara penulisannya mengalami perubahan ataupun tidak mengalami perubahan.

Kata serapan (juga kata pungutan atau kata pinjam) adalah kata yang diserap dari bahasa lain. Haugen (dalam Rukhsan, 2000:14) mengatakan bahwa pemungutan adalah reproduksi yang diupayakan dalam satu bahasa mengenai pola-pola yang sebelumnya ditemukan dalam bahasa lain. Kridalaksana (2011:112) yang kemudian menamakannya kata pinjam, menyatakan kata pinjaman adalah kata yang dipinjam dari bahasa lain dan kemudian sedikit banyaknya disesuaikan dengan kaidah bahasa sendiri.

Salah satu contoh pemakaian kata serapan adalah seorang pemakai bahasa Indonesia sering mengemukakan "sepuluh tahun" dengan kata dasawarsa, biarpun kata itu boleh dikatakan suatu "terjemahan" dari "sepuluh tahun". Mungkin di dalam pikirannya ada kata asing yang menyatakan "sepuluh tahun", katakan dari bahasa Inggris decade atau kata Belanda decade, yang menyebabkan pemakai bahasa Indonesia itu akhirnya memakai kata dasawarsa untuk menyatakan pengertian itu.

Di samping kategori di atas itu terdapat pungutan seperti kata menjajaki dari bahasa Jawa yang boleh dikatakan 
"lebih murni", karena tidak disebabkan oleh gagasan asing. Termasuk kategori ini ialah pungutan kata-kata seperti asumsi, akselerasi, asembling, eksekutif, editorial, konflik, kontraktor, proyek, teknokrat, dan lain-lain (Samsuri, 1994:52).

Berdasarkan pendapat di atas dapat disimpulkan bahwa kata serapan adalah kata yang berasal dari bahasa asing yang masuk ke dalam bahasa Indonesia akibat dari terjadinya kontak antarbahasa. Kontak tersebut menimbulkan serapan kata yang bermakna. Dalam bahasa Indonesia jika tidak ditemukan istilah yang tepat, maka bahasa asing dapat dijadikan sebagai sumber peristilahan Indonesia. Istilah baru tersebut dapat dibentuk dengan jalan menerjemahkan atau menyerap, sekaligus menerjemahkan istilah asing.

\section{Proses Penyerapan Istilah Asing}

Menurut Chaer (2008:239) penyerapan adalah proses pengambilan kosakata dari bahasa asing Eropa (seperti bahasa Belanda, bahasa Inggris, bahasa Portugis, dan sebagainya), maupun bahasa asing Asia (seperti bahasa Arab, bahasa Parsi, bahasa Sansekerta, bahasa Cina dan sebagainya), termasuk dari bahasa-bahasa Nusantara (seperti bahasa Jawa, bahasa Sunda, bahasa Minang, bahasa Bali, dan sebagainya). Artinya, penyerapan yaitu proses pengambilan unsur dari suatu bahasa (asal bahasa) ke dalam bahasa lain (bahasa penerima) yang kemudian oleh penuturnya dipakai sebagaimana layaknya bahasa sendiri. Dalam penelitian ini bahasa yang diserap berasal dari bahasa asing, yaitu Inggris dan Belanda.

Dalam KBBI (2012:51-52) disebutkan bahwa berdasarkan taraf integrasinya, proses penyerapan unsur asing dalam bahasa Indonesia dikelompokkan menjadi dua yakni adopsi dan adaptasi. Adopsi yaitu masih mengikuti cara asing. Adaptasi yaitu menyesuaikan dengan bahasa yang dimasukinya. Uraian selengkapnya adalah sebagai berikut.

\section{1) Adopsi}

Adopsi merupakan proses penyerapan unsur asing yang belum sepenuhnya terserap ke dalam bahasa Indonesia. Menurut Santoso dan Suwignyo (2008: 30) adopsi akan dilakukan jika (i) konsep keilmuan tidak terdapat dalam bahasa Indonesia, (ii) dipertahankan makna otentiknya, (iii) memang tidak dapat diindonesiakan baik secara ucapan atau penulisannya, (iv) jika diindonesiakan menghasilkan banyak sinonim/padan kata, dan (v) bersifat internasional. Adapun contoh kata yang mengalami adopsi yaitu reshuffle, shuttle cock, bag hand, smash, dan lain sebagainya.

\section{2) Adaptasi}

Adaptasi adalah proses penyerapan unsur asing yang penulisan dan pengucapannya disesuaikan dengan kaidah bahasa Indonesia. Adaptasi ialah perubahan bunyi dan struktur bahasa asing menjadi bunyi dan struktur yang sesuai dengan penerimaan pendengaran atau ucapan lidah bangsa pemakai bahasa yang dimasukinya (Muslich, 2008:102). Jadi dapat disimpulkan adaptasi merupakan pemungutan unsur asing yang penulisan dan pengucapannya disesuaikan dengan pendengaran atau ucapan lidah pemakai bahasa yang dimasukinya. Misalnya kata situasi, kondisi, orientasi, stasiun.

Penyesuaian atau adaptasi bentuk unsur serapan bahasa asing dibedakan menjadi empat, yaitu adaptasi fonologis, otografis, fonologis dan ortografis serta adaptasi morfologis. Adapatasi fonologis yaitu menyesuaikan lafal dalam bahasa Indonesia. Adaptasi ortografis yaitu menyesuaikan ejaan dalam bahasa Indonesia. Adaptasi ortografis dan fonologis yaitu menyesuaikan lafal dan ejaan dalam bahasa Indonesia.

\section{3) Adaptasi Morfologis}

Menurut Muslich (2008:103) adaptasi morfologis adalah penyesuaian struktur bentuk kata. Dengan adanya perubahan struktur bentuk kata ini maka akan berpengaruh pada perubahan bunyi dan penulisan dalam bahasa Indonesia. Misalnya kata foundation berasal dari bahasa Inggris yang kemudian diserap ke dalam bahasa 
Indonesia menjadi fondasi. Kata fondation mempunyai bentuk dasar found. Pada kata tersebut terdapat sufiks dari bahasa Inggris yaitu -(a) tion yang kemudian berubah menjadi - (a)si dalam bahasa Indonesia.

\section{4) Morfologis Afiksasi}

Morfologis afiksasi adalah peristiwa pembentukan kata dengan jalan membubuhkan afiks pada bentuk dasar. Morfologis afiksasi adalah proses morfologis dalam rangka pembentukan kata-kata kompleks (Muslich 2008:105). Adapun afiks dapat digolongkan menjadi empat macam yaitu prefiks, infiks, sufiks, dan konfiks. Bentuk prefiks dalam bahasa Indonesia seperti, ber-, se-, meN-, di-, ke-, peN-, per-, ter-. Adapun bentuk infiks adalah -el-, -em-, -er-. Bentuk sufiks adalah $-i$, -kan, -an. Konfiks adalah gabungan baik prefiks, infiks, maupun sufiks. Contohnya meN- + -I = menikmati, di- + -kan = didikan, dan ber- + -el- + -an $=$ bergelantungan.

\section{5) Morfologis Reduplikasi}

Morfologis reduplikasi adalah proses pengulangan suatu kata baik secara keseluruhan atau sebagian, baik dengan variasi fonem atau tidak. Ramlan (1997:69) menyatakan bahwa berdasarkan cara mengulang bentuk dasarnya, pengulangan dapat digolongkan menjadi empat golongan. Pertama, pengulangan seluruh, yaitu pengulangan seluruh bentuk dasar, tanpa perubahan fonem dan penambahan afiks. Dalam bahasa Indonesia misalnya kata sepeda menjadi sepeda-sepeda. Kedua, pengulangan sebagian, yaitu pengulangan sebagian dari bentuk dasar. Misalnya dari kata mengambil menjadi mengambil-ambil.

Ketiga, pengulangan yang berkombinasi dengan pembubuhan afiks, maksudnya pengulangan terjadi bersamasama dengan proses pembubuhan afiks dan bersama-sama pula mendukung satu fungsi. Dalam bahasa Indonesia, misalnya kata kereta menjadi kereta-keretaan. Keempat, pengulangan dengan perubahan fonem, yaitu pengulangan dengan perubahan bunyi. Dalam bahasa Indonesia, contohnya sangat sedikit, misalnya bolak-balik, gerak-gerik, sayur-mayur, dan sebagainya.

\section{6) Morfologis Komposisi}

Morfologis komposisi adalah hasil dan proses penggabungan morfem dasar dengan morfem dasar, baik yang bebas maupun yang terikat, sehingga terbentuk sebuah konstruksi yang memiliki identitas leksikal yang berbeda, atau yang baru. Perpaduan atau pemajemukan atau komposisi ialah proses penggabungan dua leksem atau lebih yang membentuk kata. Jadi dapat disimpulkan komposisi merupakan proses menggabungkan morfem dasar dengan morfem dasar sehingga membentuk kata baru. Kata yang terjadi dari gabungan dua kata itu lazim disebut kata majemuk. Kata majemuk ialah gabungan dua buah morfem atau lebih yang membentuk kesatuan makna dan bercirikan sebuah kata (Soegijo, 1989:63). Misalnya rumah sakit, meja makan, kepala batu, dan keras hati.

\section{Metode Penelitian}

Penelitian ini menggunakan metode deskriptif kualitatif. Penggunaan metode ini bertujuan untuk mendeskripsikan data apa adanya tentang proses pemakaian kata serapan dan istilah asing dalam rubrik Opini Harian Serambi Indonesia edisi Februari 2019.

\section{Sumber Data dan Data}

Sumber data penelitian adalah subjek, benda, atau tempat dari mana data penelitian diperoleh oleh peneliti (Arikunto, 2006:129). Sumber data penelitian ini adalah opini-opini yang dimuat pada rubrik Opini Harian Serambi Indonesia edisi Februari 2019. Adapun data penelitian ini adalah kata serapan dan istilah asing yang terdapat pada kalimat dalam rubrik Opini Harian Serambi Indonesia edisi Februari 2019 untuk dianalisis proses pemakaiannya.

\section{Teknik Pengumpulan Data}

Untuk mendapatkan data-data yang akurat, peneliti menggunakan teknik 
dokumentasi, yaitu dengan menganalisis proses pemakaian kata serapan dan istilah asing penelitian yang telah penulis tetapkan. Analisis itu melalui beberapa tahapan, yakni membaca, mengidentifikasi, dan mengumpulkan kalimat yang di dalamnya terdapat kata serapan dan istilah asing.

\section{Teknik Pengolahan Data}

Data-data yang sudah terkumpulkan, peneliti olah hingga melewati beberapa tahapan. Tahapan-tahapan itu dimulai dari mendeskripsikan data, mengelompokkan data, menanalisis proses pemakaian data, dan menarik simpulan.

\section{Pembahasan}

Setelah dilakukan penganalisisan data diketahui bahwa proses pemakaian kata serapan dan istilah asing yang terdapat pada kalimat dalam rubrik Opini Harian Serambi Indonesia edisi Februari 2019 adalah sebagai berikut.

\section{1) Adopsi}

Adopsi adalah pemungutan unsur asing yang belum sepenuhnya terserap ke dalam bahasa yang dimasukinya dalam hal ini yaitu bahasa Indonesia. Proses pemakaian kata serapan dan istilah asing yang terdapat pada kalimat dalam rubrik Opini Harian Serambi Indonesia edisi Februari 2019 berbentuk adopsi dapat ditemukan pada data-data berikut.

Data (1)

Sebab itu, kebahagiaan dan ketenangan hanya dimiliki oleh orang-orang yang qana'ah dalam menjalani kehidupan. (SI, 1/2/2019)

Kata qana'ah pada data di atas diadopsi dari istilah asing. Kata qana'ah sendiri berasal dari bahasa Arab yang bermakna 'saluran'. Oleh sebab itu, istilah asing qana'ah yang digunakan pada kalimat di atas tidak dan lafalnya mengalami perubahan ejaan atau tidak ada penyesuaian dalam bahasa Indonesia.

Data (2)

Jadi, sebagai umat Nabi, mari tunjukkan identitas kita yang saling berkasih sayang dengan sesama melalui sikap care and share, peduli dan berbagi. (SI, 1/2/2019)

Adapun bentuk care and share merupakan istilah asing. Pemakaian bentuk care and share pada kalimat di atas diadopsi dari istilah asing dan masih mempertahankan bentuk semula. Pemakaian istilah asing care and share pada kalimat di atas hanya merupakan bentuk pretise atau gengsi penulis saja. Istilah asing care and share tersebut berasal dari bahasa Inggris yang bermakna 'peduli dan berbagi'.

Data (3)

Di penghujung 2018 lalu, dalam sebuah gala di Kementerian Pariwisata, Menteri Pariwisata membeberkan capaian pembangunan di bidang yang digawanginya tersebut, salah satunya terkait dengan trend dan brand wisata halal yang kini bukan hanya menasional, tetapi telah menjadi wacana dan fenomena yang mendunia. (SI, 2/2/2019)

Kata trend dan brand pada data di atas merupakan istilah asing yang diadopsi dari bahasa Inggris. Trend artinya 'kecenderungan' dan brand artinya 'merek' (Echols dan Hassan, 2002). Perlu diketahui bahwa proses pemakaian istilah asing dalam kalimat di atas tidak terjadi perubahan apa pun bentuknya.

Data (4)

Contoh sederhana, penyelenggaraan pelatihan atau peningkatan kapasitas aparatur gampong yang dilaksanakan oleh organisasi perangkat daerah tertentu dan dibiayai dengan Dana Desa oleh seluruh gampong. (SI, 6/2/2019)

Istilah gampong merupakan istilah asing yang diambil dari bahasa Aceh. Istilah gampong bermakna 'kampung atau desa' (Bakar, 1985:46). Jika diuraikan berdasarkan fonologi, kata 'kampung' dan gampong hanya terjadinya pertukaran pada fonem $/ \mathrm{k} /$ dengan $/ \mathrm{g} /$ dan fonem $/ \mathrm{u} /$ dengan /o/. Pemakaian istilah gampong pada kalimat di atas termasuk proses adopsi.

Data (5)

Ketiga, menjauhkan risiko penyakit alzheimer. (SI, 7/2/2019) 
Istilah asing alzheimer yang terdapat dalam kalimat di atas diadopsi dari bahasa Inggris. Istilah alzheimer pada data di atas merupakan istilah asing yang muncul dalam ilmu medis. Alzheimer merupakan penyakit progresif yang menghancurkan memori dan fungsi mental penting lainnya. Oleh sebab itu, penggunaan istilah asing alzheimer pada kalimat di atas masih mempertahankan bentuk aslinya, karena belum ada padanan kata yang tepat dalam bahasa Indonesia sebagai penggantianya.

Data (6)

Setelah terucap ijab $\boldsymbol{k a b u l}$, pasangan yang baru menikah punya cita-cita untuk membangun rumah tangga seindah mungkin, seharmonis rumah tangga Rasulullah dan sahabatnya. (SI, 8/2/2019)

Penggunaan istilah asing ijab kabul pada kalimat di atas merupakan bentuk pemakaian istilah asing utuh (adopsi). Dalam hal ini, istilah ijab kabul merupakan istilah asing yang diadopsi dari Bahasa Arab. Ijab kabul adalah istilah yang keagamaan yang digunakan dalam prosesi perkawinan bagi pemeluk Islam. Dalam bahasa Indonesia, istilah ijab kabul dianggap kata yang umum karena berkenaan dengan keagamaan.

Data (7)

Gabungan faktor eksogen dan endogen tersebut yang kemudian menjadi penyebab kelainan struktural jantung terutama bila terjadi di masa pembentukan organ di trimester pertama kehamilan. (SI, 9/2/2019)

Hampir serupa dengan beberapa data sebelumnya, penggunaan istilah asing eksogen dan endogen pada kalimat di atas merupakan proses adopsi dan masih mempertahankan bentuk dasarnya karena belum ada padanan kata yang tepat dalam bahasa Indonesia. Eksogen merupakan istilah dalam biologi yang berarti 'berasal dari atau disebabkan oleh faktor-faktor luar suatu organisme. Adapun endogen merupakan istilah dalam ilmu kimia yang bermakna 'zat-zat yangt ada di luar bagian tubuh, tetapi sangat memengaruhi organisme dari tubuh itu'. Kedua istilah asing tersebut digunakan dalam medis dan berasal dari bahasa Inggris. Eksogen dan endogen diartikan sebagai penyakit yang bisa menyebabkan kebutaan permanen akibat penumpukan lemak pada jantung.

Data (8)

Bedanya, dalam pemilu sebelumnya badai hoaks lebih banyak menerpa peserta pemilu, terutama presiden dan wakil presiden. (SI, 11/2/2019)

Secara terminologi bahasa, istilah hoaks berarti 'kabar bohong'. Istilah itu akhir-akhir ini semakin populer digunakan dalam bidang politik. Oleh sebab itu, istilah asing yang belum diketahui asal-usulnya itu masih simpang siur penggunaanya dalam bahasa Indonesia sampai saat ini. Sebagian masih mempertahankan istilah hoaks dan sebagian lagi menggunakan 'hoak' .

Data (9)

Bahkan tidak hanya di dunia, engkau pasti akan ditagih sampai ke negeri akhirat. (SI, 14/2/2019)

Kata akhirat pada data di atas merupakan kata serapan yang tidak mengalami perubahan bentuk penyesuaian ke dalam bahasa Indonesia. Kata akhirat diadopsi dari bahasa Arab. Dalam KBBI Daring, kata akhirat bermakna 'alam setelah kehidupan di dunia ;alam baka'. Meskipun tidak mengalami perubahan bentuk penyesuaian ke dalam bahasa Indonesia, kata akhirat merupakan kata umum yang berkenaan dengan keagamaan.

Data (10)

Hari Valentine lazimnya disebut hari kasih sayang, dalam sejarahnya merupakan perayaan dari pengikut $\boldsymbol{S t}$ Valentine sebagai ritual keagamaan untuk memperingati kematiannya yang menyedihkan karena mengubur cintanya. (SI, 15/2/2019)

Istilah asing valentine yang terdapat dalam kalimat di atas berasal bahasa Inggris. Istilah valentine pada data di atas merupakan istilah asing yang muncul pada 
setiap tanggal 14 Februari. istilah valentine dimakanai 'hari kasih sayang'. Oleh sebab itu, penggunaan istilah asing valentine pada kalimat di atas masih mempertahankan bentuk aslinya (adopsi), karena belum ada padanan kata yang tepat dalam bahasa Indonesia sebagai penggantinya.

Data (11)

Jangan sampai terjadi sebagaimana teman saya berseloro, peumimpin geutanyoe meu meuseujid hana geutupat. (SI, 19/2/2019)

Bentuk bergaris miring yang terdapat dalam kontruksi kalimat “... peumimpin geutanyoe meu meuseujid hana geutupat." merupakan istilah asing yang diambil dari bahasa Aceh. Arti kontruksi kalimat itu adalah '...pemimpin kita Masjid saja tidak tahu di mana'. Pemakaian istilah asing dari bahasa Aceh dalam kontruksi kalimat di atas sebagai bentuk sindiran kepada pemimpin yang menjauhkan diri dari Tuhan. Adapun proses pemakaian istilah asing dari kata bahasa Aceh itu masih mempertahankan bahasa daerah yang utuh (adopsi).

Data (12)

Fakta lain di zaman now, banyak suami merasa superior dan kaku. (SI, 21/2/2019)

Penggunaan istilah asing now pada data di atas merupakan bagian dari pemakaian istilah asing dalam bahasa Indonesia. Istilah asing now diadopsi dari bahasa Inggris. Jika diterjemahkan ke dalam bahasa Indonesia, now berarti 'sekarang'. Penulis opini yang menjadi data penelitian ini masih mempertahankan bentuk istilah now meskipun padanan kata dalam bahasa Indonesia sudah ada, yaitu 'sekarang'. Hal ini semata-mata karena ia ingin tulisannya terlihat lebih menghibur dan terkesan tidak kaku.

Data (13)

Karena itulah mengapa umat Islam harus concern terhadap hadis. (SI, 22/2/2019)

Istilah concern pada kalimat di atas adalah bentuk istilah asing yang diadopsi dari bahasa Inggris yang berarti 'perhatian'. Proses penggunaan istilah asing pada kalimat di atas tidak terjadi penyesuaian apa pun, karena penulis opini itu tidak menggunakan kata 'perhatian' dan masih memperthankan istilah concern.

Data (14)

Dari segi agama pun cara-cara seperti ini tidak etis, karena merupakan bentuk riya', 'ujub, dan sum'ah. (SI, 25/2/2019)

Istilah asing riya', 'ujub, dan sum'ah yang terdapat pada kalimat di atas merupakan adopsi dari bahasa Arab. Padahal, kata-kata tersebut telah terjadi penyesuaian dalam penyerapannya ke bahasa Indonesia, yakni dalam bentuk 'riya', 'ujub', dan 'sumah'. Namun, dalam kalimat itu penulis masih mempertahankan bentuk aslinya dengan alasan prestise atau gengsi.

Data (15)

Andai tidak terjadi pembatasan presidential treshold dalam UU No.7 Tahun 2017, ketegangan tidak seperti ini. (SI, 26/2/2019)

Hampir sama kasusnya dengan data (14) sebelumnya, data (15) terdapat bentuk istilah asing presidential treshold yang diadopsi penulis opini dari bahasa Inggris. Istilah asing itu termasuk dalam istilah yang digunakan dalam bidang birokrasi dan hukum. Dalam bahasa Indonesia terdapat padanan kata yang sesuai dengan istilah presidential treshold, yaitu 'keputusan presiden'. Namun, karena alasan prestise, penulis opini ini masih mempertahankan istilah presidential treshold untuk digunakan dalam opininya.

2) Adaptasi

Adaptasi adalah proses penyerapan unsur asing yang penulisan dan pengucapannya disesuaikan dengan kaidah bahasa Indonesia. Proses pemakaian kata serapan dan istilah asing yang terdapat pada kalimat dalam rubrik Opini Harian Serambi Indonesia edisi Februari 2019 berbentuk adaptasi ditemukan pada data-data berikut. 
Data (16)

Dalam debat capres RI 2019, publik sedikit sekali mendapatkan informasi tentang ada tidak simulasi oleh capres 01 dan 02, dan kalau ada, berapa kali, serta siapa sosok yang bertindak sebagai "Prabowo-Sandi" dan "JokowiMa'ruf". (SI, 13/2/2019)

Kata publik pada data di atas merupakan kata serapan yang mengalami bentuk penyerapan penyesuaian (adaptasi). Kata tersebut diserap dari bahasa Inggris yaitu dari kata public. Echols dan Hassan (2002:455) mengartikan kata public mempunyai makna (1) umum, orang banyak, masyarakat; (2) rakyat. Kata tersebut telah diserap dalam bahasa Indonesia dengan proses penyesuaian ejaan sesuai dengan kaidah bahasa Indonesia.

Berdasarkan Pusat Pembinaan dan Pengembangan Bahasa (dalam KBBI, 2010:83), fonem konsonan /c/ pada akhir kata public berubah menjadi konsonan $/ \mathrm{k} /$ sehingga kata public (bahasa Inggris) setelah mengalami penyesuaian kaidah bahasa Indonesia hanya diubah seperlunya menjadi publik dan lafalnya menggunakan ejaan bahasa Indonesia.

Data (17)

Jadi, sebuah harapan disandarkan kepada guru sebagai salah satu elemen penting dalam pendidikan, menjadi penyemai dan penumbuh nilai-nilai adab pada anak-anak didiknya. (SI, $16 / 2 / 2019$ )

Kata elemen diturunkan penyerapan dari kata element yang berasal dari bahasa Inggris. Proses penyerapan kata element ke dalam bahasa Indonesia terjadinya penyesuaian (adaptasi). Penyesuaian yang terjadi adalah adanya proses pelesapam fonem /t/ pada kata element menjadi elemen.

Data (18)

Pemerintah hanya boleh mengarahkan

program CSR agar bersinergi dengan program pemerintah. (SI, 17/2/2019)

Kata program pada kalimat di atas telah mengalami penyesuaian ke dalam bahasa Indonesia (adopsi). Kata program diserap dari bahasa Inggris yaitu dari kata programm. Dalam KBBI kata program berarti (1) rancangan mengenai asas serta usaha yang dijalankan; (2) urutan perintah yang diberikan pada komputer untuk membuat fungsi atau tugas tertentu.

Data (19)

Dan karena setiap belanja itu menghasilkan efek ganda, tentu uang yang sebesar Rp 736 miliar tersebut menghasilkan efek ganda menjadi triliunan rupiah. (SI, 27/2/2019)

Kata efek pada kalimat di atas merupakan kata serapan yang dipungut dari bahasa Inggris, effect. Kata effect telah disesuaikan proses penyerapannya (adaptasi) ke dalam bahasa Indonesia dengan cara pelesapan dan penggantian fonem. Pelesapan fonem terjadi pada dua fonem /f/. Mula-mula fonem /f/, /f/ pada kata itu dilesapkan satu, sehingga tinggal satu fonem /f/. Pelesapan lainnya adalah pada fonem /c/ dan /t/ yang dilesapkan adalah fonem /t/. Akibat pelesapan tersebut juga terjadinya subtitusi fonem /c/ ke fonem $/ \mathrm{k} /$, sehingga kata effect akhirnya dalam bahasa Indonesia dieja dan ditulis menjadi efek.

Data (20)

Sebagai masyarakat, kita tak perlu panik dan fokus mencari-cari kesalahan terkait polemik Plt di Pemerintahan Aceh. (SI, 28/2/2019)

Kata fokus erupakan kata serapan yang mengalami bentuk penyesuaian dengan ejaan kaidah bahasa Indonesia (adaptasi). Kata tersebut diserap dari bahasa Inggris yaitu dari kata focus. Dalam penyesuaiannya, kata focus menjadi fokus dalam bahasa Indonesia. Dalam proses penyerapannya konsonan /c/ di tengah kata focus berubah menjadi konsonan $/ \mathrm{k} /$ sehingga kata focus (bahasa Inggris). Dengan demikian, kata fokus sudah tidak asing dan sudah termasuk dalam keluarga kosakata bahasa Indonesia.

\section{3) Morfologis Afiksasi}

Proses morfologis afiksasi adalah proses pembentukan kata-kata baru dengan cara menggabungkan dua morfem, seperti 
membubuhkan afiks pada kata dasar. Proses pemakaian kata serapan dan istilah asing yang terdapat pada kalimat dalam rubrik Opini Harian Serambi Indonesia edisi Februari 2019 berupa morfologis afiksasi terdapat pada data berikut.

Data (21)

Hadirnya gosip politik hingga kampanye hitam dapat menjadi batu sandungan dan bom waktu bagi degradasi demokrasi. (SI, 12/2/2019)

degradasi pada data di atas merupakan kata serapan yang muncul karena ilmu pengetahuan dan teknologi yang masuk dalam bahasa Indonesia dan berasal dari luar negeri. Kata degradasi ini merupakan kata serapan yang masuk dalam bahasa Indonesia dikarenakan lebih bersifat Internasional daripada padanannya. Kata degradasi berasal dari kata degradation. Dalam proses penyerapan ke dalam bahasa Indonesia terjadinya proses morfologis afiksasi berupa subtitusi infiks, yaitu dari akhiran asing -tion menjadi akhiran -si.

Data (22)

Krisis-krisis ini pada gilirannya telah mengancam kelangsungan sumbersumber kehidupan rakyat. (SI, 24/2/2019)

Kata serapan krisis-krisis yang merupakan bentuk pengulangan dari kata yang dipungut dari bahasa Inggris cricis. Kata cricis ketika diserap ke dalam bahasa Indonesia telah terjadi penyesuaian dalam bentuk substitusi fonem, yaitu menggantikan fonem $/ \mathrm{c} / \mathrm{ke}$ fonem $/ \mathrm{k} /$. Proses penyerapan kata asing tersebut digolongkan ke proses morfologis afiksasi.

\section{Simpulan}

Berdasarkan hasil pembahasan dan analisis data, dapat disimpulkan bahwa proses pemakaian kata serapan dan istilah asing yang dipungut ke dalam bahasa Indonesia pada opini Serambi Indonesia edisi Februari 2019 terdapat tiga bentuk proses, yaitu (1) proses adopsi, (2) proses adaptasi, dan (3) proses morfologis afiksasi.

Kata serapan dan istilah asing yang dipungut ke dalam bahasa Indonesia pada opini Serambi Indonesia edisi Februari 2019 diadopsi, diadaptasi, dan berproses morfologis dari beberapa bahasa, yaitu bahasa Inggris, bahasa Arab, dan bahasa daerah Aceh. Rinciannya, proses adopsi ditemukan pada istilah asing dari bahasa Inggris, bahasa Arab, dan bahasa daerah Aceh. Proses adaptasi ditemukan pada kata serapan dari bahasa Inggris dan bahasa Arab. Proses morfologis afiksasi hanya ditemukan pada kata serapan dari bahasa Inggris.

Dalam penelitian ini ditemukan adanya proses adopsi mengenai pemakaian istilah dari bahasa Aceh dalam opini Serambi Indonesia edisi Februari 2019 cukup beralasan. Hal tersebut dilatarbelakngi oleh alih kode bahasa, sebab hamper semua penulis opini pada Serambi Indonesia berasal dari Aceh.

\section{Daftar Pustaka}

Arikunto, Suharsimi. 2006. Prosedur Penelitian: Suatu Pendekatan Praktik. Jakarta: Rineka Cipta.

Chaer, Abdul. 2008. Morfologi Bahasa Indonesia: Pendekatan Proses. Jakarta: Rineka Cipta.

Chaer, Abdul dan Leonie Agustina. 2004. Sosiolinguistik Perkenalan Awal. Jakarta: Rineka Cipta.

Depdiknas. 2014. Kamus Besar Bahasa Indonesia. Jakarta: Balai Pustaka.

Echols, John M. dan Hassan Shadily. 2010. Kamus Inggris Indonesia. Jakarta: Gramedia.

Kridalaksana, Harimurti. 2011. Kamus Linguistik. Edisi Keempat. Jakarta: PT. Gramedia Pustaka Utama.

Muslich, Masnur. 2008. Tata Bentuk Bahasa Indonesia: Kajian ke Arah Tatabahasa Deskriptif. Jakarta: Bumi Aksara. 
Jurnal Sains Riset (JSR)

$p$-ISSN 2088-0952, $e$-ISSN 2714-531X

Ohoiwutun, Paul. 2007. Sosiolinguistik. Jakarta: Kesaint Blanc.

Poerwadarminta. 1985. Kamus Besar Bahasa Indonesia. Jakarta: Balai Pustaka.

Ramlan, Muhammad. 1997. Morfologi Tinjauan Deskriptif. Yogyakarta: CV. Karyono.

Samsuri. 1994. Analisis Bahasa. Jakarta: Erlangga.

Surat Kabar Harian Serambi Indonesia Edisi Februari 2017. Banda Aceh: Media Grafika.

Suwignyo, Heri dan Anang Santoso. 2008. Bahasa Indonesia Keilmuan. Malang: Universitas Negeri Malang.

Tarigan, Henry Guntur. 1994. Membaca Sebagai Suatu Keterampilan Berbahasa. Bandung: PT Raja Grafindo Persada.

Wibowo, Wahyu. 2001. Otonomi Bahasa: 7 Strategi Tulis Pragmatik Bagi Praktisi Bisnis dan Mahasiswa. Jakarta: Gramedia Pustaka Utama. 